\title{
BREEDING AND PARENTAL CARE IN THE ENDANGERED TEHUANTEPEC JACKRABBIT (LEPUS FLAVIGULARIS)
}

\author{
Tamara Rioja ${ }^{1,4}$, Consuelo Lorenzo ${ }^{2}$, Eduardo Naranjo ${ }^{2}$, Laura Scott ${ }^{3}$, and Arturo Carrillo-Reyes ${ }^{4,5}$
}

\begin{abstract}
We documented date and duration of each breeding phase, breeding rate, nursing behavior, parental care, and leveret survival of the Tehuantepec jackrabbit (Lepus flavigularis), a critically endangered lagomorph. Between June 2006 and May 2008, we observed 60 adult radio-collared jackrabbits in Oaxaca, México. Tehuantepec jackrabbits exhibit breeding behaviors 250 days out of the year, with a high-intensity period during the rainy season (May-October). Females give birth to 2 leverets 32 days after copulation. Directly after birth, leverets are put into "beds" or "nests," which are depressions in the ground covered by prairie grass (Jouvea pilosa). Females return to nurse and groom the leverets once per day until the leverets are weaned (12 days after birth). The breeding season and parental care behaviors of Tehuantepec jackrabbits are similar to those of other jackrabbits. Females produced an average of 2 litters per breeding season. The breeding rate for the Tehuantepec jackrabbit (4 leverets per breeding female per breeding season) is lower than the average of other species in the genus Lepus. The survival rate of Tehuantepec jackrabbit leverets (50\% at day 19$)$ is higher than that of other leporids. Predation by domestic dogs (Canis familiaris) is the main cause of mortality. Understanding reproductive behavior is critical for captive breeding, reintroduction, and conservation efforts for endangered leporids such as the Tehuantepec jackrabbit.
\end{abstract}

RESUMEN.-Documentamos la fecha y la duración de cada fase de la reproducción, la tasa reproductiva, el amamantamiento, el cuidado parental y los instintos de supervivencia de los lebratos de la liebre de Tehuantepec (Lepus flavigularis), un lagomorfo en peligro crítico de extinción. Entre junio de 2006 y mayo de 2008 observamos 60 liebres adultas con collares radiotransmisores en Oaxaca, Mexico. Las liebres de Tehuantepec se reproducen 250 días del año, con un período de alta intensidad durante la estación lluviosa (de mayo a octubre). Las hembras paren 2 lebratos 32 días después de la cópula; colocan a los lebratos en "camas", o huecos en el suelo cubiertos del pasto Jouvea pilosa, justo después de nacer. Las hembras regresan para amamantar y limpiar a los lebratos una vez cada tarde hasta destetarlos 12 días después de nacer. La temporada de reproducción y el cuidado parental de la liebre de Tehuantepec son parecidos a los de otras liebres. En promedio, las hembras producen 2 crías cada temporada de reproducción. La tasa de reproducción de la liebre de Tehuantepec (4 lebratos por hembra reproductora por temporada de reproducción) está por debajo del promedio de otras especies del género Lepus. La tasa de supervivencia de los lebratos de la liebre de Tehuantepec (50\% al día 19) es superior a la que se ha documentado para otros lepóridos, siendo la principal causa de mortalidad la depredación por los perros domésticos (Canis familiaris). Es crucial entender el comportamiento reproductor para la crianza en cautiverio, la reintroducción y para los esfuerzos de conservación de lepóridos que están en peligro de extinción tal como occure con la liebre de Tehuantepec.

Often, reproductive behavior is poorly understood for rare, cryptic, or endangered species of conservation concern (Cote 2003). Understanding reproductive behavior is critical to managing habitat, developing captive-breeding protocols for recovering endangered species, and reestablishing locally extirpated populations (Rakes et al. 1999, Maier 2001, Festa-Bianchet and Apollonio 2003, Mattingly et al. 2003, Reichard and Boesch 2003).

Recently, conservation efforts in the region of the Isthmus of Tehuantepec, Oaxaca, México, have focused on 4 populations of the Tehuantepec jackrabbit (Lepus flavigularis). The Tehuantepec jackrabbit is an endemic lagomorph that is critically endangered because of habitat loss and fragmentation (e.g., hunting and genetic isolation) (Flux and Angermann 1990, Baillie and Groombridge 1996, SEMARNAT 2001, Farías et al. 2008, Carrillo-Reyes et al. 2010). Tehuantepec jackrabbits survive along savannas and grassy dunes on the shores of the Superior and Inferior lagoons, which are bodies of saltwater connected to the Gulf of Tehuantepec (Lorenzo et al. 2008).

Little is known about the reproductive biology of the Tehuantepec jackrabbit. The limited data have come from 2 studies that provide some details about the breeding season and mating system of this lagomorph (Farías et al. 2006, Rioja et al. 2008). We describe, for the first time

${ }^{1}$ Universidad de Ciencias y Artes de Chiapas, 1a. Av. Sur Poniente 1460 Centro. C.P. 29000, Tuxtla Gutiérrez, Chiapas, México.

${ }^{2}$ El Colegio de la Frontera Sur, Departamento de Ecología y Sistemática Terrestres, Carretera Panamericana y Periférico Sur s/n. C. P. 29290, San Cristóbal de Las Casas, Chiapas, México.

${ }^{3}$ Facultad de Ciencias Forestales, Universidad Autónoma de Nuevo León. Carretera Panamericana km 145 s/n, Linares, N. L. México

${ }^{4}$ Oikos: Conservación y Desarrollo Sustentable, A.C. Del Sol 22, Colonia Bismark. C.P. 29267, San Cristóbal de las Casas, Chiapas, México.

5Corresponding author. E-mail: acarrillo@oikos.org.mx 


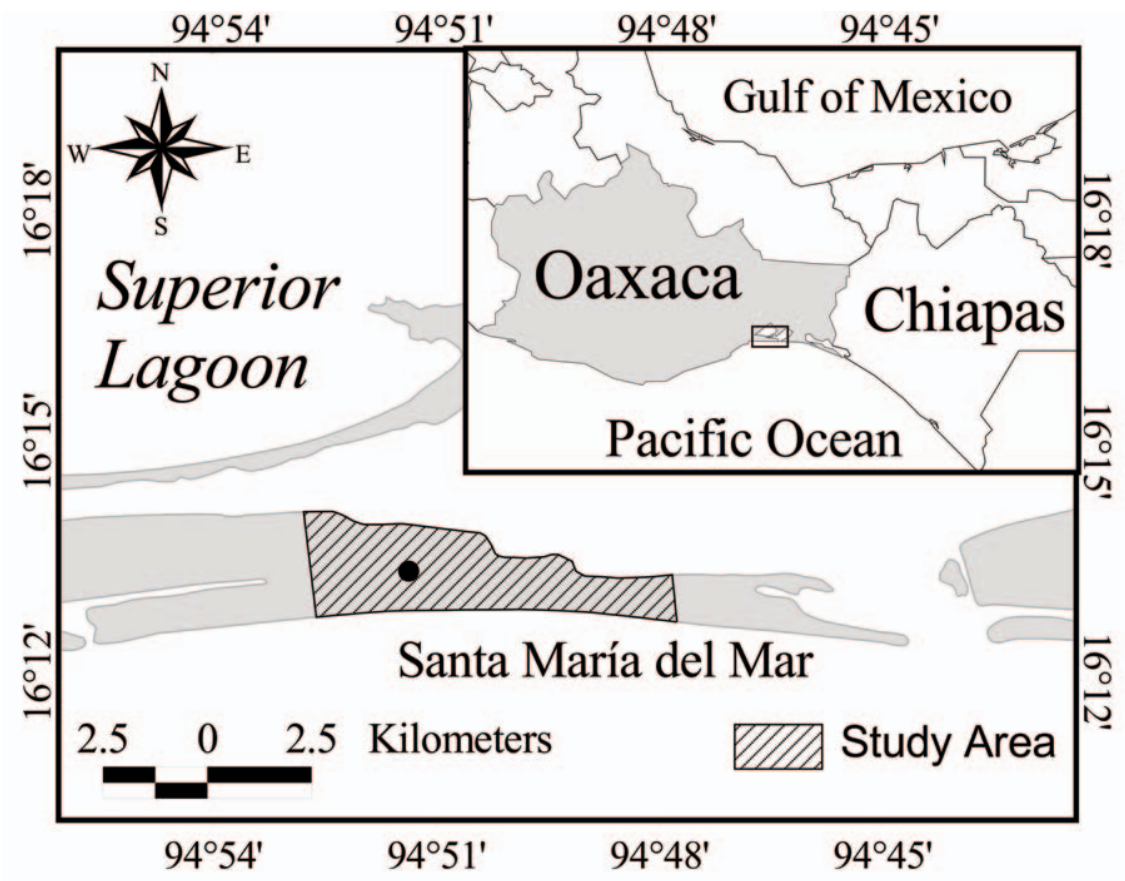

Fig. 1. Study area at Santa María del Mar, southeastern Oaxaca, México.

and on the basis of field observations, breeding and parental care of the Tehuantepec jackrabbit. We also provide an update for the recently published information on duration of the breeding season (Rioja et al. 2008).

\section{Methods \\ Study Site}

The study site was located in the southern region of the Isthmus of Tehuantepec, Oaxaca, México. We studied the Tehuantepec jackrabbit population that occupies $14.33 \mathrm{~km}^{2}$ on a 5-km-long sandy peninsula (Vargas 2000) located between Laguna Superior and the Gulf of Tehuantepec in the vicinity of Santa María del $\operatorname{Mar}\left(16^{\circ} 14^{\prime} 12.53^{\prime \prime} \mathrm{N}, 94^{\circ} 57^{\prime} 58.72^{\prime \prime} \mathrm{W}\right.$ and $16^{\circ} 12^{\prime}$ $\left.15.83^{\prime \prime} \mathrm{N}, 94^{\circ} 45^{\prime} 39.82^{\prime \prime} \mathrm{W}\right)$, municipality of Juchitán de Zaragoza (Fig. 1).

The climate of this region is tropical and seasonally variable, with a mean annual temperature of $25^{\circ} \mathrm{C}$ and a mean annual rainfall of $800 \mathrm{~mm}$ (García 1964). The rainy season is from May through October, and the dry season extends from November through April (Zizumbo and Colunga 1982). The vegetation consists mainly of open grasslands located on plains, valleys, and hills characterized by the presence of Jouvea pilosa and zones of xerophitic shrublands, predominantly Opuntia tehuantepecana and Opuntia decumbens (Vargas 2000, Pérez-García et al. 2001).

Santa María del Mar has a population of 739, mostly Huave indigenous people (INEGI 2000, Vargas 2000). Fishing, cattle husbandry, and agriculture constitute the main anthropogenic activities. The cattle graze on approximately 34 pasture fields distributed among the grasslands, which are the areas of greater jackrabbit activity (Carrillo-Reyes et al. 2010). Both agriculture and cattle husbandry have limited the distribution of Tehuantepec jackrabbit in the study area because the sites for feeding and refuge of the species are eliminated when the natural vegetation is removed (Vargas 2000).

Historically, poaching is an activity carried out in Santa María del Mar by locals from the community of San Mateo del Mar and the cities of Salina Cruz and Juchitán. They hunt, for personal and commercial purposes (Vargas 2000, Carrillo-Reyes et al. 2010; Municipal agent of Santa María del Mar, personal communication), several species such as armadillo (Dasypus novemcinctus), deer (Odocoileus virginianus), raccoon (Procyon lotor), and, mainly, Tehuantepec jackrabbit. Currently, community authorities protect Tehuantepec jackrabbit with surveillance 
and poaching fines (Municipal Agent of Santa María del Mar, personal communication).

However, in the isthmus region, poaching and consumption of terrestrial vertebrates continue to be common activities rooted deeply in tradition and sustained by the impoverished social and economic conditions prevailing in Santa María del Mar (Vargas-Espíndola 2001).

\section{Capture and Handling of Jackrabbits}

A total of 60 adult jackrabbits (26 males and 34 females) from the Santa María del Mar population were sampled using day and night captures. During the day, we walked through grasslands and bushy areas in order to direct jackrabbits to a 1-m-high, 40-m-long fishing net. This method was used in the bushy areas and in the bushgrassland transition zones. At night, we drove a pickup truck through grasslands and dunes, and along the beach. We located jackrabbits using 2 spotlights, which were attached to the vehicle and which illuminated a distance of up to $100 \mathrm{~m}$ (Farías et al. 2006). Spotlights were directed at jackrabbits to dazzle their vision, and they were then cornered by several people and captured with a handheld fishing net 3-4 $\mathrm{m}$ in diameter. These capture methods were very successful because they allowed us to minimize handling time and eliminate the threat of injury to the animals (Farías et al. 2006).

Once captured, specimens were immediately transferred from the net into cotton bags for handling. To avoid stressing the animals, we covered the eyes of captured jackrabbits with a hood and worked as quickly as possible. We recorded sex by visual inspection of the penis or clitoris, body mass by using a hanging scale, body measures (total length, tail length, back-leg length, and ear length; Adams 1959, Péroux 1995), and age (juvenile or adult). A jackrabbit was considered an adult when it had an approximate weight of $\geq 1.8 \mathrm{~kg}$ and length of $\geq 55.6 \mathrm{~cm}$ (criteria defined by Vorhies and Taylor 1933). All adult jackrabbits were fitted with radio-collars (35 g, 24 months of battery life, activity/mortality sensor, model TX-35/24, $148 \mathrm{MHz}$, TELENAX, México; Adams 1959, Gray 1989, Kowicz et al. 1990). Juvenile specimens were measured and then released. When a breeding site was detected, we recorded the precise coordinates of the site with a handheld GPS unit (Garmin eTrex Legend ${ }^{\circledR}$ ). We recorded basic measures (weight and total length) of the leverets. This was done once the female walked away and could no longer see the bed. Measurements were taken in less than one minute to reduce the chances of the mother returning and parental care being affected. The leverets were captured with gloved hands and placed immediately in a cloth bag for weighing with a Pesola ${ }^{\circledR} 100$-g vertical scale (precision $\pm 0.3 \%$ ). Subsequently, we measured total length with a flexible tape. Finally, the leverets were placed in the exact bed in which they were found. During the process, we took care that the site was not disturbed in any way. Our research complied with all current Méxican laws and was conducted under authorization of the Méxican government (SEMARNAT 2001). The capture and handling of jackrabbits also followed guidelines approved by the American Society of Mammalogists (OLAW-ARENA 2002).

\section{Monitoring}

We radio-tracked the jackrabbits intensively from June 2006 to May 2008. We completed 12 periods of monitoring during 2 years of study, each one with a duration of $30-40$ days. Jackrabbits were radio-located and monitored by direct observation, using TRX-1000 portable receivers equipped with a 3-element Yagi antenna (Farías et al. 2006, Carrillo-Reyes et al. 2010). Also, 29 fixed-observation sites distributed throughout the study site were selected. These observation sites were located in key areas where congregations of radio-collared jackrabbits visited frequently.

To avoid interfering with the behavior of the jackrabbits, we observed jackrabbits from prudent distances of 50-100 m. During monitoring, active jackrabbits continued feeding or interacting socially. We recorded the time (hour and minutes) when the radio-tracked individual was sighted, and then we waited until the jackrabbit walked away before obtaining Universal Transverse Mercator (UTM) coordinates for the sighting locations. UTM coordinates were obtained using a handheld GPS unit. We recorded jackrabbit activity throughout the 24-hour cycle. Daytime observations were conducted from 06:00 to 19:00, and nighttime observations were conducted from 19:00 to 06:00. When a jackrabbit was detected, we began a monitoring period of at least 12 hours to identify any reproductive behaviors. If an individual did not show any such behavior, we proceeded to find another jackrabbit and monitor it for reproductive behaviors. When we encountered a jackrabbit that showed reproductive behaviors (including 
nursing or parental care), we monitored it for periods of 18-24 hours every day until the behavior ceased. If a breeding site was found, the position and the number of leverets were recorded, and we monitored the site continuously until the female appeared. In all cases, we kept a safe distance of $50-100 \mathrm{~m}$ from the observed individuals, in order to reduce the chances of affecting their behavior. We were able to observe the leverets directly after or within a few hours of birth. Once the leverets were born, they stayed in a single "bed" that females scratched under prairie grass (J. pilosa); this type of hard grass provides almost complete coverage for leverets. The leverets moved short distances, allowing the observer to continue monitoring them and not lose sight of them (Gray 1989, Kowicz et al. 1990). We ceased monitoring reproductive behaviors after 30 days, just when the leverets reached the size of young jackrabbits and when they could disperse to greater distances, often outside the scope of the observer.

We considered the breeding season as the period between onset of the mating season and end of the weaning period (Hansen 1992, Rioja et al. 2008). We considered males to be reproductively active when they had enlarged, black testes and when they exhibited reproductive behaviors such as approaching females and smelling their vulvas. Females were considered to be in estrus when they permitted reproductively active males to approach (Boone et al. 2003, Elias et al. 2006). By means of direct observation (Gray 1989, Angerbojorn and Flux 1995), we registered each radio-tracked jackrabbit mating encounter. We recorded gestation period (date of copulation to date of birth), breeding rate (number of leverets per litter and number of litters per breeding female), nursing behavior (number of days spent nursing, number of nursing sessions per day, and time spent nursing per day; Elias et al. 2006), parental care (grooming of the leverets; Gray 1989), and survival of leverets through the first 30 days of life (the time period during which we could consistently monitor leverets because they remained in their beds during the day hours; O'Donoghue 1994).

Every observation was carried out using a terrestrial telescope (Leica Televid ${ }^{\mathrm{TM}}$ APO-77 telescope, 20X-60X ocular lens) and binoculars (Konus Vue ${ }^{\mathrm{rM}}$, Giant Zoom 10-30 X 60) during the daytime, and night-vision oculars (Odissey ${ }^{\mathrm{TM}}$ NON03, 3X, 15000X sensitivity) and halogen lights with red filters for nighttime and crepuscular observations (Gray 1989, Kowicz et al. 1990, Rioja et al. 2008).

We obtained seasonal information about habitat and atmospheric variables to evaluate the relationship between seasons and Tehuantepec jackrabbit breeding. Habitat characteristics were obtained from 6 fixed plots located randomly in the grassland (Tehuantepec jackrabbit habitat; Hays et. al. 1981, Franco-López et. al. 1996). We recorded plant species, frequency, and aerial cover (the percentage of ground surface covered by the aerial canopy of a plant, line-intercept method) of all shrubs and herbaceous vegetation present within each fixed plot. We also obtained monthly information on ambient temperature, pluvial precipitation, and photoperiod (Rioja 2008); atmospheric variables were recorded by a meteorological station located in Santa María del Mar (Del Mar University, Oaxaca, México), as well as by a rain gauge (Byline Logging Rain Gauge, RG2 Onset $\left.{ }^{\circledR}\right)$.

\section{Data Analysis}

Results are reported as means with standard deviations, except where otherwise noted (Ellsworth and Reynolds 2006). Survival curves for the leverets were calculated using the KaplanMeier procedure (Pollock et al. 1989, O’Donoghue 1994, Gillis and Krebs 2000), a nonparametric estimator that allows censoring of data (i.e., animals living beyond the duration of the study) and staggered entry of animals (Pollock et al. 1989). The Kaplan-Meier seasonal survival curves were compared using Mantel-Cox and generalized Wilcoxon's tests (Cox 1970, O’Donoghue 1994, Gillis and Krebs 2000). We used a multiple linear regression approach to evaluate the effect of several predictors (independent variables): forb and shrub coverage, temperature, rain, and photoperiod. We also evaluated the interactions of predictors on the number of radio-tracked individuals per month undergoing each of the breeding phases (reproductively active males, females in estrus, females in gestation, and nursing females). Separate analyses were performed for every breeding phase against all independent variables. All variables were natural-log transformed before analyses to satisfy assumptions of normality and equal variance among groups of data (Sokal and Rohlf 1995). The best model was chosen using a stepwise algorithm with standardized variables. Predictor variables were excluded when low correlation 


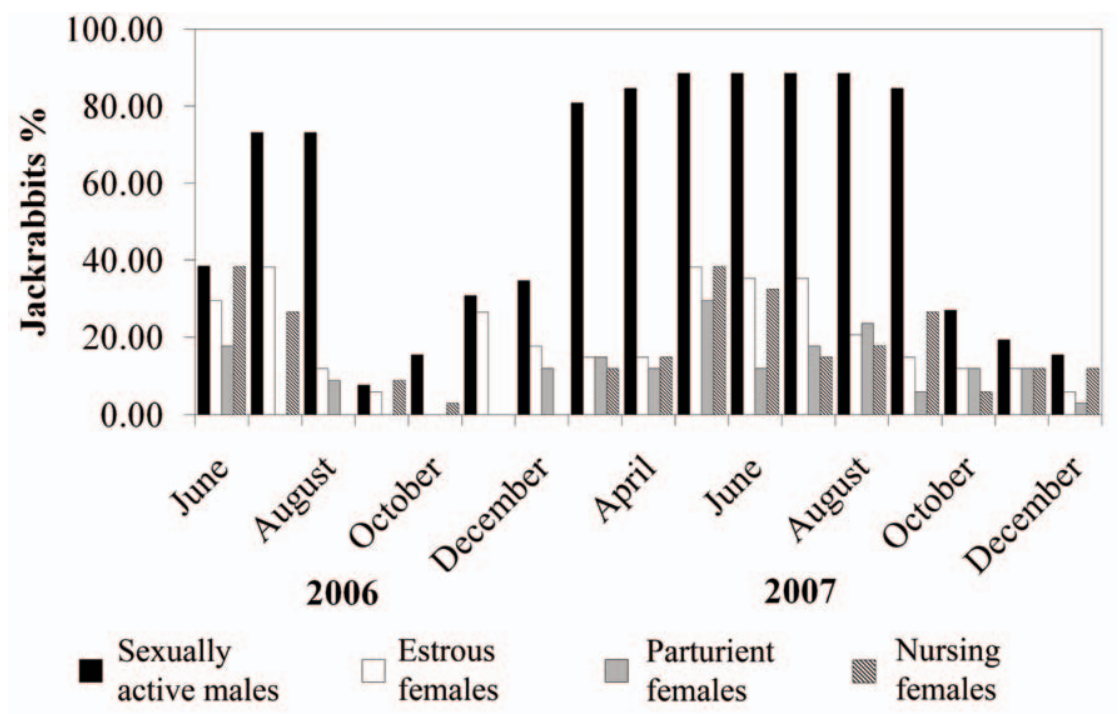

Fig. 2. Breeding season of the Tehuantepec jackrabbit in Santa María del Mar, Oaxaca, México.

and significance $(P>0.05)$ were obtained (Weisberg 1985). We used SPSS ${ }^{\circledR}$ Statistics v16 software (Baldwin et al. 2004, Serrouya et al. 2007).

\section{REsults}

\section{Breeding Season}

We registered 3 different breeding seasons, corresponding to the years 2006,2007 , and 2008. The complete duration of the breeding season was recorded only for 2007 , because our study was initiated in mid-2006 and culminated in mid-2008 with the end of the useful life of the radio-collars.

The Tehuantepec jackrabbit population in Santa María del Mar had an average breeding season of 250 days per year $(n=45)$, beginning in late January and ending in early November. More intense reproductive activity occurred during the rainy season (May-October), when we observed an increase of reproductively active males $(20.17 \pm 6.46)$ and parturient or nursing females (8.83 \pm 3.97; Fig. 2).

We recorded date and duration of each breeding phase. Males were sexually active from mid-January to early November, with a peak of activity from May to October (23 radio-tracked males). We recorded the female estrus phase from the beginning of February to the end of September. The most intense sexually active period for females was from March through July, as we observed the greatest number of females in estrus (30 radio-tracked females) during this period. We recorded mating activity from the beginning of February through the end of September. The gestation phase was recorded from the beginning of February until mid-October, and the highest number of pregnant females (30 radio-tracked females) was documented from May through August. During this phase, we observed an increase of corporal volume in the radio-tracked females, which was a clear sign of gestation. The length of gestation was 32.06 \pm 3.88 days $(n=30)$, during which females were accompanied by other females, and males were observed mounting the females until the day their leverets were born. The nursing phase was observed from the beginning of March through the beginning of November. The most intense period of nursing was from May through September, as we documented the peak number of nursing females (30 radio-tracked females) during this time. Nursing females were characterized by thin bodies, blackish and turgid nipples, as well as matted hair around the teats; at the end of this phase, females exhibited gaunt bodies and mammaries with limp skin.

During the rainy season we also documented an increase of the ambient temperature, pluvial precipitation, photoperiod, and cover of forbs. Regression analysis indicated that photoperiod, temperature, and pluvial precipitation were the variables which best predicted breeding phases; the model excluded both herbaceous and shrub 
TABLE 1. Regression model of the effects of herbaceous and shrub cover, precipitation, temperature, and photoperiod on the breeding phases of the Tehuantepec jackrabbit. The final model included variables presented in the table (less significant predictors were excluded, and the main effects with a significant interaction were retained).

\begin{tabular}{|c|c|c|c|c|c|}
\hline Breeding phase & $\mathrm{R}^{2}$ & $\beta$ & $\mathrm{SE}$ & $t$ & $P$ \\
\hline \multicolumn{6}{|l|}{ Females in estrus } \\
\hline Model & 0.554 & & & & \\
\hline Photoperiod & & 1.979 & 0.254 & 7.795 & $<0.001$ \\
\hline Temperature & & 1.413 & 0.250 & 5.566 & $<0.001$ \\
\hline \multicolumn{6}{|c|}{ Females in gestation } \\
\hline Model & 0.677 & & & & \\
\hline Photoperiod & & 1.412 & 0.155 & 9.084 & $<0.001$ \\
\hline Precipitation & & 0.449 & 0.124 & 2.890 & 0.008 \\
\hline \multicolumn{6}{|l|}{ Nursing females } \\
\hline Model & 0.673 & & & & \\
\hline Photoperiod & & 1.244 & 0.168 & 7.388 & $<0.001$ \\
\hline \multicolumn{6}{|c|}{ Reproductively active males } \\
\hline Model & 0.630 & & & & \\
\hline Photoperiod & & 1.471 & 0.242 & 6.077 & $<0.001$ \\
\hline
\end{tabular}

covers (Table 1). Temperature and photoperiod were the variables that best predicted timing of estrus in females, and both showed a positive effect on estrus phase. Precipitation and photoperiod explained the number of parturient females in a positive relationship. Nursing females were best predicted by a positive relationship with precipitation and photoperiod. Photoperiod was the variable that best explained the number of sexually active males, showing a positive effect of day length on the probability of finding reproductively active males (Table 1 ).

\section{Breeding Rate}

We recorded production of 240 leverets throughout the study. Forty-seven leverets were produced by 17 radio-collared females during 2006; 136 leverets were produced by 30 females during 2007; and 57 leverets were recorded from 16 females during 2008.

We recorded an average of $4.53 \pm 0.81 \mathrm{lev}-$ erets born per breeding female in a single breeding season. A breeding female produced an average of $1.97 \pm 0.18$ litters per breeding season, each one composed of $2.27 \pm 0.60$ leverets $(n=30)$.

\section{Nursing Behavior and Parental Care}

We documented nursing behavior and parental care for the 240 leverets produced by 30 radio-tracked females throughout the study. Tehuantepec jackrabbit females were the only care providers to the leverets; the males did not intervene. Once the leverets were born, the females put them in their "beds." The beds are similar to those reported for L. europaeus and
L. callotis (Chapman et al. 1982, Nowak 1999). Tehuantepec jackrabbit leverets were precocial and fully furred, and their eyes opened within an hour of birth. Total length was $16 \pm 0.5 \mathrm{~cm}$ and weight was $50 \pm 1.2 \mathrm{~g}$. When the leverets were $2.10 \pm 1.02$ days old $(n=240)$, they were capable of moving with small jumps; however, they did not move beyond their beds. Maternal females visited the leverets to nurse and groom them once a day, usually at night. After the female arrived, the leverets left the nests and situated themselves under the mother to suckle for $20.18 \pm 4.04$ minutes $(n=240)$, while the mother licked them. After the suckling ended, the leverets retired to their bed and did not leave it again until the next nursing bout. In some cases $(n=30)$, it was possible to hear the female call the leverets by means of a shriek, and the young answered, emitting several shrieks similar to those of a child. For litters with more than 2 leverets $(n=118)$, the young were separated by females into different beds at $5.00 \pm 2.68$ days of age. Distance between these beds was $2.03 \pm$ $1.07 \mathrm{~m}$. The leverets were nursed for $12.01 \pm 2.15$ days $(n=240)$; thereafter, they were weaned and abandoned. Once weaned and abandoned, the leverets only left their beds at night to feed. During this stage, the leverets fed for most of the evening and into the dawn, at distances from their beds averaging $50.7 \pm 12.32 \mathrm{~m}(n=240)$; the leverets spent an average of $5.01 \pm 1.13$ hours away from their bed. At $30.03 \pm 7.57$ days of age $(n=106)$, the distances from the beds to where they fed increased to $200.71 \pm 15.34 \mathrm{~m}$; after that, young no longer returned to their beds, and we were unable to continue monitoring them. 


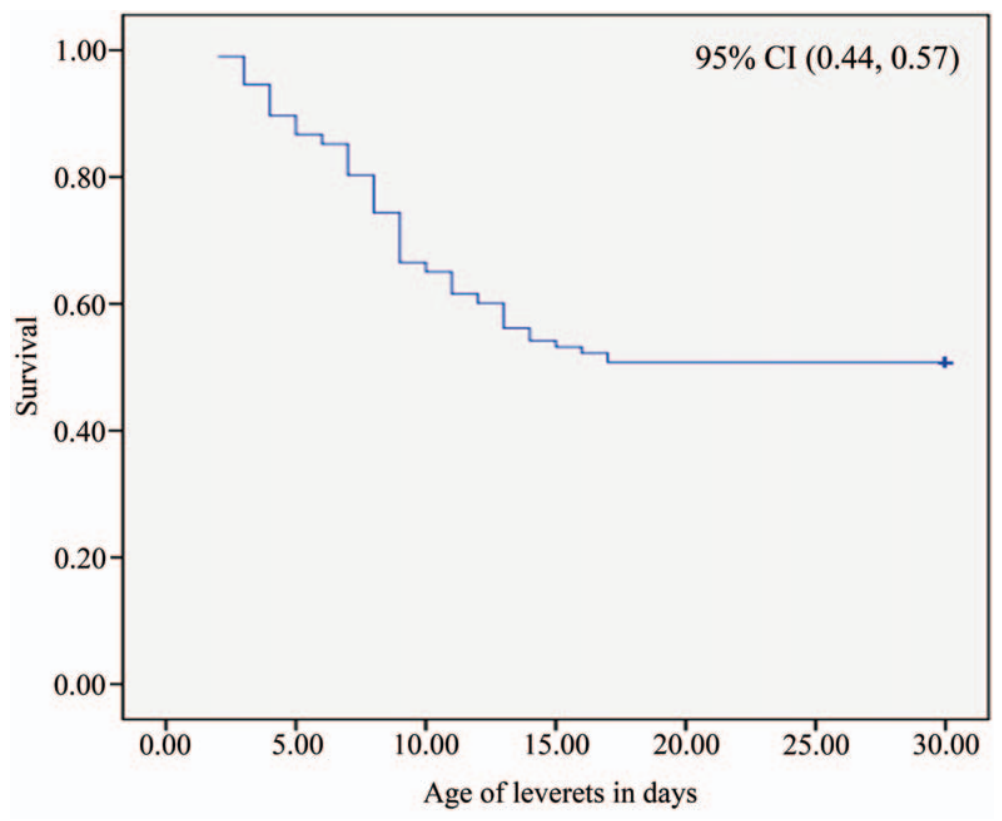

Fig. 3. Kaplan-Meier survival curve of Tehuantepec jackrabbit leverets. The mean survival percentage was $50 \%$ at day 19.

\section{Survival of Leverets}

We documented the survival of 240 leverets produced by 30 radio-tracked females throughout the study. The Kaplan-Meier test showed that, on average, the survival to 19 days was $50.7 \%$ ( $n=240$; Fig. 3). Survival of leverets during the dry season was $42.6 \%$ to 17 days, whereas during the rainy season, survival was $53.2 \%$ to 19 days. The Mantel-Cox test $\left(\chi^{2}=\right.$ 1.806, $P>0.179)$ and generalized Wilcoxon's test $\left(\chi^{2}=1.712, P>0.191\right)$ both showed that there was no significant difference in the survival of leverets between seasons. We did not witness infanticide, and the main cause of leveret mortality was the presence of 2 predators: snakes and domestic dogs (Canis familiaris). We registered 102 deaths throughout our monitoring. Thirty leverets died because of predation by snakes (Masticophis mentovarius, Drymobius margaritiferus, and Trimorphodon biscutatus), and 13 leverets died because of predation by groups of 2-5 domestic dogs from the Santa María del Mar population. Other possible causes of mortality were unknown.

\section{Discussion}

The breeding season for the Tehuantepec jackrabbit seems to be similar to that of hares and other jackrabbits (i.e., Lepus californicus, Lepus europaeus, and Lepus insularis; Banfield 1974, Hewson and Taylor 1975, Godin 1977, Nowak 1999). Our results present an update to the breeding-season duration previously reported by Rioja et al. (2008) who reported jackrabbits breeding 200-250 days per year, based on increased availability of field information.

Reproductive activities increased during the rainy season, and multiple linear regression analysis suggested that this population experiences reproductive synchrony, a common phenomenon in other jackrabbits such as L. americanus. During the reproductive synchrony, L. americanus undergoes various reproductive stages to coincide with the wet season, in which there is also greater availability of resources (Ims 1987, O’Donoghue and Boutin 1995, Maier 2001). The wet season (defined by photoperiod, ambient temperature, and pluvial precipitation) determines the productivity of forbs, which in turn influences the availability and quality of food (nutrients and energy) jackrabbits need to survive and carry out each of their breeding phases, especially gestation and nursing. This pattern is similar for L. californicus, L. europaeus, L. americanus, Lepus timidus, and Lepus arcticus (Lechleitner 1959, Parker 1977, Vaughan and Keith 1981, Clarck and Innis 1982, Lochmiller et al. 
1982, Boutin 1984, Angerbojorn 1986, O’Donoghue and Krebs 1992, Portales et al. 2004). Our results could be clear evidence of this relationship, since the periods of greatest reproductive activity coincided with the wet season, in which we recorded the highest coverage values $(90.17 \%)$ when compared to the dry season $(22.82 \%)$. It is also probable that the increase of photoperiod length and ambient temperature during the rainy season influences the reproductive hormones of females and males, activating a phase of sexual activity in both sexes, as seen with $L$. americanus (Davies and Meyer 1972, Ellsworth and Reynolds 2006), L. timidus, and L. californicus (Angerbojorn 1986, Portales et al. 2004). Variables such as photoperiod length and ambient temperature can be used as predictors of breeding phases (Bronson 1989). Monitoring these variables can provide information useful for conservation and management programs for Tehuantepec jackrabbits in Santa María del Mar, Oaxaca.

The breeding rate of Tehuantepec jackrabbits (4 leverets per female per breeding season) is lower than the average recorded for Lepus: $L$. californicus can produce 4 litters per year with 6 leverets per litter (Hanselka et al. 1971, Godin 1977); L. insularis can produce 3 litters per year with 4 leverets per litter; L. europaeus and $L$. timidus scoticus can produce 4 litters per year with 2 leverets per litter (Flux 1970, Stott et al. 2008); L. arcticus can produce 5 litters per year with 2 leverets per litter (Banfield 1974, Parker 1977); and L. americanus can produce 4-10 litters per year with 4 leverets per litter (Banfield 1974, Cary and Keith 1979, Ellsworth and Reynolds 2006). Although the litter size of L. flavigularis (2 leverets) is similar to that of $L$. arcticus, L. californicus, L. t. scoticus, and L. europaeus (Bronson and Tiemeier 1958, Flux 1970, Banfield 1974, Stott et al. 2008), fewer litters are produced by the Tehuantepec jackrabbit ( 2 per breeding season) than by most of the other Lepus species: 4 litters in L. californicus (Bronson and Tiemeier 1958), 5 litters in $L$. arcticus (Banfield 1974), 3 litters in L. insularis (Flux 1981), and 4 litters in L. americanus (Ellsworth and Reynolds 2006). Flux (1967) affirms that it is normal for jackrabbits with long breeding seasons to have fewer litters, unlike other jackrabbits with breeding seasons lasting an average of 180 days (i.e., L. americanus and Lepus townsendii; Chapman et al. 1982, Ellsworth and Reynolds 2006).
The Tehuantepec jackrabbit does not place its leverets in open areas without plant cover, like Gray (1989) and Kowicz et al. (1990) reported for L. arcticus. Furthermore, the Tehuantepec jackrabbit does not put leverets under trees or shrubs as do L. americanus and Lepus callotis (Adams 1959, Chapman et al. 1982). Tehuantepec jackrabbits place their leverets in "beds," or depressions that the females excavate under prairie grass (J. pilosa). These depressions are an excellent refuge for leverets because they are almost completely hidden (Rioja 2008). This behavior is similar to that of $L$. capensis, in which females also place leverets in depressions under grass to protect them from possible predators (Nowak 1999). We found that the nursing behavior of Tehuantepec jackrabbits is also similar to that documented for other Lepus species; leverets are nursed once every evening and spend most of the day alone in their bed within their mother's home range (Rioja 2008). Similar nursing behavior has been reported for L. arcticus, L. americanus, and L. europaeus (Rongstad and Tester 1971, Broekhuizen and Maaskamp 1980, Kowicz et al. 1990, Hackländer et al. 2002). This behavior of nursing once a day is apparently well adapted to minimizing predation risks. Jackrabbits and hares have highly concentrated milk (Martinet and Demarne 1984), which allows them to nurse for short, infrequent periods, thus minimizing the amount of time that the whole litter is out of the bed and exposed to predators (Rongstad and Tester 1971, Martinet and Demarne 1984, O’Donoghue and Bergman 1992). The natal beds, which provide protection for the offspring and seem necessary for successful reproduction, potentially could be affected by land management practices such as livestock grazing. An inefficient livestock management program could reduce vegetation cover because of grazing (Lorenzo et al. 2008). Consequently, this issue needs to be addressed in future field studies.

The survival rate of Tehuantepec jackrabbit leverets (50\% survive to day 19) was higher than that reported for other Lepus species in similar periods of monitoring: $42 \%$ for L. californicus, $15 \%-46 \%$ for L. americanus (Wagner and Stoddart 1972, Boutin and Krebs 1986, O’Donoghue 1994), and 50\% for L. europaeus (Pépin 1989). The principal predator of the Tehuantepec jackrabbit leverets in our study area was the domestic dog. In accordance with Sime (1999), the negative impact that domestic dogs can exercise on populations of wild animals was evident. The 
dogs are efficient predators of leverets and also represent potential vectors for diseases (dysentery or parvovirus) and parasites. In order to best manage leverets, this issue needs to be addressed in management and conservation programs.

Tehuantepec jackrabbit populations in Santa María del Mar, Oaxaca, showed reproductive behaviors similar to those of other leporids, even to those species at high latitudes like L. arcticus and L. americanus. This similarity suggests evolution of comparable ethological reproductive strategies in northern and southern species, which is especially noteworthy because the distribution of the Tehuantepec jackrabbit is entirely tropical. This information provides the opportunity for evolutionary studies that can facilitate a better comprehension of how the environment shapes behavior, reproduction, and life history of the different Lepus species.

\section{Management Implications}

Knowledge of reproductive patterns is fundamental to captive-breeding programs and to conservation and management efforts for the Tehuantepec jackrabbit. Also, we know that protecting suitable habitat for the Tehuantepec jackrabbit is essential if the species is to persist (Farías et al. 2006, Lorenzo et al. 2008). As Farías et al. (2006) confirmed, Tehuantepec jackrabbits inhabit savannas and grassy dunes, which are part of the lands used by local families from southern Oaxaca, and the jackrabbits are jeopardized by disturbances such as growth of human settlements, cattle-raising activities, frequent fires, and poaching. However, leveret survival was higher than reported for other Lepus species, and we can suppose that suitable land-management practices do not represent a threat for this population. Nevertheless, land management is a challenge in an area with some of the highest poverty indices in Mexico and permanent ethnic conflicts. Consequently, it is imperative to work simultaneously for biological conservation and projects of social development.

Also, we noted that the main predator of the Tehuantepec jackrabbit leverets was the domestic dog. The presence of dogs is connected with deeprooted practices of fishermen. However, we believe that a conservation and management program that includes local workshops and environmental education can solve this problem; we can give local people information regarding the importance of maintaining dogs in town and not permitting them into the grassland areas. Currently, our team is developing a new research and management program in collaboration with local people and conservation organizations. Our main objectives are to study the unknown aspects of the Tehuantepec jackrabbit, while we seek for implementation of conservation and management measures to ensure the survival of the species.

\section{ACKNOWLEDGMENTS}

We acknowledge the Consejo Nacional de Ciencia y Tecnología (CONACyT) through the Fondos Mixtos de Apoyo a la Investigación Científica CONACyT-Gobierno del Estado de Chiapas (CHIS-2005-C03-001) for its contributions to this research. Also, we thank the municipal and communal authorities of Santa María del Mar, Juchitán de Zaragoza, Oaxaca, and especially to the Gutierrez Vázquez and Antonio Gutierrez families for their collaboration. We are grateful to all students from El Colegio de la Frontera Sur, Universidad de Ciencias y Artes de Chiapas, and Benemérita Universidad Autónoma de Puebla, for their help during capture efforts. We thank V. Farías for her help with the first stages of this research. Finally, we thank anonymous reviewers for their comments and suggestions that led to this manuscript's improvement.

\section{Literature Cited}

ADAMS, L. 1959. An analysis of a population of snowshoe hares in northwestern Montana. Ecological Monographs 29:141-170.

Angerbojorn, A. 1986. Reproduction of mountain hares (Lepus timidus) in relation to density and physical condition. Journal of Zoology 208:559-568.

Angerbojorn, A., AND J.E.C. Flux. 1995. Lepus timidus. Mammalian Species 495:1-11.

Baillie, J., AND B. Groombridge. 1996. IUCN Red List of threatened animals. International Union for Conservation of Nature and Natural Resources, Gland, Switzerland. 368 pp.

Baldwin, R.A., A.H.M. Kennedy, And P.S. Liu. 2004. An assessment of microhabitat variables and capture success of striped skunks (Mephitis mephitis). Journal of Mammalogy 85:1068-1076.

BANFIELD, A. 1974. Mammals of Canada. University of Toronto Press, Toronto, Ontario, Canada. 438 pp.

Boone, W.R., M.E. Richardson, and J.A. Greerb. 2003. Breeding behavior of the American black bear Ursus americamus. Theriogenology 60:289-297.

Boutin, S. 1984. Effect of late winter food addition on numbers and movements of snowshoe hare. Oecologia 62: 393-400.

Boutin, S., And C.J. Krebs. 1986. Estimating survival rates of snowshoe hare. Journal of Wildlife Management 50: 592-594.

Broekhuizen, S., AND F. MaAskamp. 1980. Behavior of does and leverets of European hare Lepus europaeus 
whilst nursing. Journal of Zoology London 191: 487-501.

BRONSON, F.H. 1989. Mammalian reproductive biology. University of Chicago Press, Chicago, IL. 319 pp.

Bronson, F.H., AND O.W. Tiemeier. 1958. Reproduction and age distribution of black-tailed jackrabbits in Kansas. Journal of Wildlife Management 22:409-414.

Carrillo-Reyes, A., C. Lorenzo, E. Naranjo, M. Pando, AND T. RIOJA. 2010. Home range dynamics of the Tehuantepec jackrabbit in Oaxaca, Mexico. Revista Mexicana de Biodiversidad 81:143-151.

CaRY, J.R., AND L.B. KeITH. 1979. Reproductive change in the 10-year cycle of snowshoe hares. Canadian Journal of Zoology 57:375-390.

Chapman, J., J. Dunn, and R. Marsh. 1982. Lepus townsendii. Pages 124-137 in J.A. Chapman and G.A. Fledhamer, editors, Wild mammals of North America: biology, management, and conservation. Johns Hopkins University Press, Baltimore, MD.

ClarCK, W.R., AND G.S. InNIS. 1982. Forage interactions and black-tailed jackrabbit population dynamics: a simulation model. Journal of Wildlife Management 46: 1018-1035.

CotE, I.M. 2003. Knowledge of reproductive behavior contributes to conservation programs. Pages 77-92 in M. Festa-Bianchet and M. Apollonio, editors, Animal behavior and wildlife conservation. Island Press, Washington, DC.

Cox, D.R. 1970. Analysis of binary data. Methuen, United Kingdom.

Davies, G.J., AND R.K. Meyer. 1972. The effect of day length on pituitary FSH and LH and gonadal development of snowshoe hare. Biological Reproduction 6:264-269.

Elias, B.A., L.A. Shipley, R.D. SaYLER, and R.S. Lamson. 2006. Mating and parental care in captive pygmy rabbits. Journal of Mammalogy 87:921-928.

Ellsworth, E., and T.D. Reynolds. 2006. Snowshoe hare (Lepus americanus): a technical conservation assessment. USDA Forest Service, Rocky Mountain Region. 68 pp.

Farías, V., T.K. Fuller, F.A. Cervantes, and C. Lorenzo. 2006. Home range and social behavior of the endangered Tehuantepec jackrabbit (Lepus flavigularis) in Oaxaca, México. Journal of Mammalogy 87:748-756. 2008. Conservation of critically endangered lagomorphs: the Tehuantepec jackrabbit (Lepus flavigularis) as an example. Pages 363-368 in P. Célio Alves, N. Ferrand, and K. Hackländer, editors, Lagomorph biology: evolution, ecology and conservation. SpringerVerlag, Berlin, Germany.

Festa-Bianchet, M., and M. Apollonio. 2003. Animal behavior and wildlife conservation. Island Press, Washington, DC. $322 \mathrm{pp}$.

FLuX, J.E.C. 1967. Reproduction and body weights of the hare Lepus europaeus Pallas in New Zealand. New Zealand Journal of Science 10:357-401.

1970. Life history of the mountain hare (Lepus timidus scoticus) in north-east Scotland. Journal of Zoology 161:75-123.

1981. Reproductive strategies in the genus Lepus. Pages 155-174 in K. Myers and C.D. Mac, editors, Proceedings of the World Lagomorph Conference. University of Guelph Press, Ontario, Canada.

Flux, J.E.C., AND Angermann, R. 1990. The hares and jackrabbits. Pages 61-94 in J.A. Chapman and G.A. Feldhamer, editors, Rabbits, hares and pikas: status survey and conservation action plan. International Union for
Conservation of Nature and Natural Resources, Gland, Switzerland.

Franco-López, J., G. De la Cruz, G. Cruz, A. Rocha, N. Navarrete, G.M. Flores, E.M. Cato, S.C. SÁnchez, L.G.A. ABARCA, AND C.M.S. BEDiA. 1996. Manual de ecología. Trillas, México. Pages 93-100.

GarCía, E. 1964. Modificaciones al sistema de clasificación climática de Köpen (para adaptarlo a las condiciones de la República Mexicana). Instituto de Geografía, Universidad Nacional Autónoma de México, México.

Gillis, E.A., and C.J. Krebs. 2000. Survival of dispersing versus philopatric juvenile snowshoe hares: do dispersers die? Oikos 90:343-346.

GoDIN, A.J. 1977. Wild mammals of New England. Johns Hopkins University Press, Baltimore, MD. 304 pp.

GraY, D.R. 1989. Reproductive behavior of arctic hare (Lepus arcticus). Symposium Sur les Stratégies du Comportement. Duschesnay, Quebec, Canada.

Hackländer, K., W. ARnold, and T. Ruf 2002. Postnatal development and thermoregulation in the precocial European hare (Lepus europaeus). Journal of Comparative Physiology 172:183-190.

Hanselka, C.W., J.M. Inglis, and H.G. Applegate. 1971. Reproduction in the black-tailed jackrabbit in southwestern Texas. Southwestern Naturalist 16: 214-217.

HANSEN, K. 1992. Reproduction in European hare in a Danish farmland. Acta Theriologica 37:27-40.

Hays, R.L., C. Summers, and W. Seitz. 1981. Estimating wildlife habitat variables. FWS/OBS-81/47, Western Energy and Land Use Team, USDI Fish and Wildlife Service, Washington, DC. $111 \mathrm{pp}$

Hewson, R., AND M. TaYlor. 1975. Embryo counts and length of the breeding season in European hares in Scotland from 1960-1972. Acta Theriologica 20: 247-254.

IMS, R.A. 1987. Responses in spatial organization and behavior to manipulations of the food resource in the vole Cleithrionomys rufocanus. Journal of Animal Ecology 56: 585-596.

[INEGI] Instituto Nacional de Estadística, Geografía E Informática. 2000. XII Censo General de Población y Vivienda 2000. México.

Kowicz, A.B., T.H. Hamilton, D.R. GraY, and C. Downes. 1990. Nursing behavior of arctic hare (Lepus arcticus). Pages 643-664 in C.R. Harington, editor, Canada's missing dimension: science and history in Canadian arctic islands. Canadian Museum of Nature, Ottawa, Ontario, Canada.

LECHLEITNER, R.R. 1959. Sex ratio, age classes and reproduction of the black-tailed jack rabbit. Journal of Mammalogy 40:63-81.

LOCHMILLER, R.L., J.B. WhELAND, AND R.L. KiRKPATRICK. 1982. Energetic cost of lactation in Microtus pinetorum. Journal of Mammalogy 63:475-481.

Lorenzo, C., T. Rioja, A. Carrillo, and F. Cervantes. 2008. Population fluctuations of Lepus flavigularis (Lagomorpha: Leporidae) at Tehuantepec Isthmus, Oaxaca, Mexico. Acta Zoológica Mexicana 24:207-220.

Maier, R. 2001. Sistemas de apareamiento y competencia postcopulatoria. Pages 1-582 in R. Maier, editor, Comportamiento animal-Un enfoque evolutivo y ecológico. McGraw-Hill, Madrid, Spain.

Martinet, L., AND Y. Demarne. 1984. Nursing behavior and lactation in the brown hare (Lepus europaeus) raised in captivity. Acta Zoologica Fennica 171: 187-190. 
Mattingly, H.T., J. Hamilton, and D.L. Galat. 2003. Reproductive ecology and captive breeding of the threatened Niangua darter Etheostoma nianguae. American Midland Naturalist 149:375-383.

NOWAK, R.M. 1999. Walker's mammals of the world. Johns Hopkins University Press, Baltimore, MD. Pages 1720-1738.

O’Donoghue, M. 1994. Early survival of juvenile snowshoe hares. Ecology 75:1582-1592.

O’Donoghue, M., AND C.M. Bergman. 1992. Early movements and dispersal of juvenile snowshoe hares. Canadian Journal of Zoology 70:1787-1791.

O’Donoghue, M., AND S. Boutin. 1995. Does reproductive synchrony affect juvenile survival rates of northern mammals? Oikos 74:115-121.

O’Donoghue, M., and C.J. Krebs. 1992. Effects of supplemental food on snowshoe hare reproduction and juvenile growth at a cyclic population peak. Journal of Animal Ecology 61:631-641.

[OLAW-ARENA] OfFice of Laboratory Animal WelfareApplied Research Ethics National Association. 2002. Institutional Animal Care and Use Committee Guidebook. 2nd edition. Office of Laboratory Animal Welfare, National Institutes of Health, Bethesda, MD. $210 \mathrm{pp}$.

Parker, G.R. 1977. Morphology, reproduction, diet, and behavior of the arctic hare (Lepus arcticus monstrabilis) on Axel Heiberg Island, Northwest Territories. Canadian Field-Naturalist 91:8-18.

PÉPIN, D. 1989. Variation in survival of brown hare (Lepus europaeus) leverets from different farmland areas in the Paris basin. Journal of Applied Ecology 26:13-23.

Pérez-García, E.A., J. Meave, and C. Gallardo. 2001. Vegetación y flora de la región de Nizanda, istmo de Tehuantepec, Oaxaca, México. Acta Botánica Mexicana 56:19-88.

Péroux, R. 1995. Le liévre d'Europe. Bulletin Mensuel de l'Office National de la Chasse 204:1-96.

Pollock, K.H., S.R. Winterstein, C.M. Bunck, AND P.D. CuRTIS. 1989. Survival analysis in telemetry studies: the staggered entry design. Journal of Wildlife Management 53:7-15.

Portales, G.L., L. Hernández, F.A. Cervantes, and J.W. LAUNDRÉ. 2004. Reproduction of black-tailed jackrabbits (Lagomorpha: Lepus californicus) in relation to environmental factors in the Chihuahuan desert, México. Southwestern Naturalist 49:359-366.

Rakes, P.L., J.R. Shute, and P.W. Shute. 1999. Reproductive behavior, captive breeding, and restoration ecology of endangered fishes. Environmental Biology of Fishes $55: 31-42$

REICHARD, U.H., AND C. BoEsCH. 2003. Monogamy: mating strategies and partnerships in birds, humans and other mammals. Cambridge University Press, United Kingdom. 267 pp.

RiojA, T. 2008. Comportamiento reproductivo de la liebre de Tehuantepec (Lepus flavigularis) en su hábitat. Thesis, El Colegio de la Frontera Sur, México. 194 pp.

Rioja, T., C. Lorenzo, E. Naranjo, L. Scott, and A. CarRILlo-Reyes. 2008. Polygynous mating behavior in the endangered Tehuantepec jackrabbit (Lepus flavigularis). Western North American Naturalist 68:343-349.

RONGSTAD, O.J., AND J.R. TESTER. 1971. Behavior and maternal relations of young snowshoe hares. Journal of Wildlife Management 35:338-346.

[SEMARNAT] Secretaría de Medio Ambiente y RecurSOS Naturales. 2001. Norma Oficial Mexicana NOM059-ECOL-2001. Protección ambiental-especies nativas de México de flora y fauna silvestres-categorías de riesgo y especificaciones para su inclusión, exclusión o cambio-lista de especies en riesgo. Diario Oficial de la Federación, México 1:1-22.

Serrouya, R., N. McLellan, and J.P. Flaa. 2007. Scaledependent microhabitat selection by threatened mountain caribou (Rangifer tarandus caribou) in cedar-hemlock forests during winter. Canadian Journal of Forest Research 37:1082-1092.

Sime, C.A. 1999. Domestic dogs in wildlife habitats. Pages 1-300 in G. Joslin and H. Yoomans, editors, Effects of recreation on Rocky Mountain wildlife: a review for Montana. Committee on Effects of Recreation in Wildlife, MT.

SOKaL, R.R., AND FJ. RoHLF. 1995. Biometry: the principles and practice of statistics in biological research. 3rd edition. W.H. Freeman and Co., New York, NY. 887 pp.

Stott, P., S. Harris, and N. Wight. 2008. Fertility and infertility in the European hare Lepus europaeus in Australia. Pages 225-240 in P. Célio Alves, N. Ferrand, and K. Hackländer, editors, Lagomorph biology: evolution, ecology and conservation. Springer-Verlag, Berlin, Germany.

VARGAS, C. 2000. Distribución, abundancia y hábitat de la liebre endémica Lepus flavigularis (Mammalia: Lagomorpha). Thesis, Universidad Nacional Autónoma de México, D.F. 70 pp.

VARGAS-EsPíndDOLA, Z.F. 2001. Valoración de los vertebrados terrestres por huaves y zapotecas del istmo de Tehuantepec, Oaxaca, México. Thesis, El Colegio de la Frontera Sur, S.C.L.C., Chiapas. 73 pp.

Vaughan, M.R., and L.B. Keith. 1981. Demographic response of experimental snowshoe hare populations to overwinter food shortage. Journal of Wildlife Management 45:354-380.

Vorhies, C.T., AND W.P. TAYLOR. 1933. The life histories and ecology of jackrabbits Lepus alleni and Lepus californicus ssp. in relation to grazing in Arizona. University of Arizona, Technical Bulletin 49:471-587.

WAGNER, F.H., AND L.C. STODDART. 1972. Influence of coyote predation on black-tailed jackrabbit populations in Utah. Journal of Wildlife Management 36:329-342.

Weisberg, S. 1985. Applied linear regression. 2nd edition. John Wiley \& Sons, New York, NY.

Zizumbo, D., AND P. Colunga. 1982. Los huaves. La apropiación de los recursos naturales. Universidad Autónoma Chapingo, Texcoco, Estado de México. $420 \mathrm{pp}$.

Received 13 July 2009

Accepted 2 September 2010 